\title{
An effective way to deal with predators is to taste terrible: Primary and secondary psychopathy and mate preference
}

\author{
Alyson Blanchard ${ }^{\mathrm{a}, *}$, Minna Lyons ${ }^{\mathrm{b}}$, Luna Centifanti ${ }^{\mathrm{c}}$ \\ a Department of Psychological Sciences, Eleanor Rathbone Building, University of Liverpool, L69 7ZA, United Kingdom \\ ${ }^{\mathrm{b}}$ University of Liverpool, United Kingdom \\ c Durham University, United Kingdom
}

\section{A R T I C L E I N F O}

\section{Article history:}

Received 19 October 2015

Received in revised form 15 December 2015

Accepted 16 December 2015

Available online $\mathrm{xxxx}$

\section{Keywords:}

Primary psychopathy

Secondary psychopathy

Mate preference

Long and short-term relationships

Assortative mating

\begin{abstract}
A B S T R A C T
Despite their reputation for taking advantage of other people, previous research shows that psychopathic individuals are attractive for short-term relationships. Furthermore, individuals with psychopathic traits have been found to be attracted to other psychopathic persons in both short and long-term relationships. The current study $(N=258)$, is the first to extend the investigation further by examining whether these findings pertain to the affective (i.e., primary) or behavioural (i.e., secondary) aspects of psychopathy, and if this varies according to sex. Using a series of personality profiles, we found that men and women evaluated individuals higher in primary or secondary psychopathic traits unattractive for both short and long-term relationships. However, those individuals higher in primary and secondary psychopathic traits found similar partners attractive in short and long-term relationships, and this was strongest in women higher in primary psychopathic traits for long-term relationships, and in women higher in secondary psychopathic traits for short and long-term relationships. Results are discussed from an evolutionary theoretical perspective.
\end{abstract}

(c) 2015 Elsevier Ltd. All rights reserved.

\section{Introduction}

Psychopathic individuals are callous, manipulative, impulsive and irresponsible (Hare, 2003). Their toxicity would be expected to not bode well for romance. They engage in risky sexual behaviour (Fulton, Marcus, \& Payne, 2010), mate poach (Jonason, Li, \& Buss, 2010), are sexually aggressive (Mouilso \& Calhoun, 2012), and enjoy multiple sexual partners (Visser, Pozzebon, Bogaert, \& Ashton, 2010). It is unsurprising that psychopathy negatively affects relationship satisfaction and commitment (Smith et al., 2014; Visser et al., 2010). Nevertheless, studies show that people find psychopathic individuals attractive at least for short-term romantic encounters (Jonason, Lyons, \& Blanchard, 2015), which raises the question, what is it that people find alluring about a psychopathic partner?

The aversive nature of psychopathic individuals suggests that they must offer something else in a relationship. In the context of mating psychology, "good genes" is perhaps the answer. Women perceive socially dominant behaviour (Kruger, Fisher, \& Jobling, 2003), conspicuous consumption (Griskevicius et al., 2007), sexual attractiveness, and charisma (Durante, Griskevicius, Simpson, Cantú, \& Li, 2012) as indicators of genetic quality, which are all associated with psychopathy (Babiak, Neumann, \& Hare, 2010; Lee et al., 2013; Verona, Patrick, \& Joiner, 2001). Men's preference for psychopathic traits in women is

\footnotetext{
* Corresponding author.

E-mail address: aeblanch@liverpool.ac.uk (A. Blanchard).
}

less well understood, perhaps because psychopathy is hypothesised to have provided fitness only to males and not to females (Jonason, $\mathrm{Li}$, Webster, \& Schmitt, 2009). Yet, it is possible that psychopathic women are attractive to men as they similarly pursue short-term relationships and may offer the opportunity for an affair.

However, the literature has yet to address how psychopathic traits associated with "good genes" pertain to primary and secondary psychopathy, which is important considering there are phenotypic and possible etiological differences between them (Mealey, 1995). Primary psychopathy refers to the affective and interpersonal characteristics of psychopathy (e.g., callousness and manipulation); secondary psychopathy concerns the behavioural aspects of psychopathy (e.g., impulsivity and reactive aggression). Thus, primary psychopathy is described as "successful", and secondary psychopathy as "unsuccessful" (Vidal, Skeem, \& Camp, 2010). Negative outcomes associated with secondary psychopathy include anxiety (Schmitt \& Schmitt \& Newman, 1999), negative urgency (Whiteside \& Lynam, 2001), emotional-instability, poor interpersonal functioning (Ray, Poythress, Weir, \& Rickelm, 2009). Primary psychopathic individuals do not experience negative urgency or anxiety (Anestis, Anestis, \& Joiner, 2009), are assertive (Levenson, Kiehl, \& Fitzpatrick, 1995) and good at emotion management (Donahue, McClure, \& Moon, 2014). They succeed in business environments (Babiak et al., 2010), are ambitious and self-disciplined (Mullins-Sweatt, Glover, Derefinko, Miller, \& Widiger, 2010), which, with the ability to manipulate, confers success in high-ranking professions (Skeem, Polaschek, Patrick, \& Lilienfeld, 2011). However, 
Descriptive statistics for ratings of high and low primary and secondary psychopathic personality profiles in different mating contexts.*

\begin{tabular}{|c|c|c|c|c|c|c|c|c|c|c|}
\hline & \multicolumn{10}{|l|}{ Mean (SD) } \\
\hline & \multicolumn{5}{|c|}{ Primary psychopathy } & \multicolumn{5}{|c|}{ Secondary psychopathy } \\
\hline & High & Low & $t$ & $d$ & $d f$ & High & Lower & $t$ & $d$ & $d f$ \\
\hline \multicolumn{11}{|l|}{ Women } \\
\hline Short-term mating & $1.27(.49)$ & $1.55(.37)$ & $-6.71^{* *}$ & -0.64 & 150 & $1.27(.55)$ & $1.67(.36)$ & $-8.49^{* *}$ & -0.86 & 150 \\
\hline Long-term mating & $.92(.45)$ & $1.83(.38)$ & $-17.29^{* *}$ & -2.19 & 150 & $.91(.49)$ & $1.91(.37)$ & $-17.83^{* *}$ & -2.3 & 150 \\
\hline \multicolumn{11}{|l|}{ Men } \\
\hline Short-term mating & $1.35(.50)$ & $1.56(.33)$ & $-3.99^{* *}$ & -0.5 & 106 & $1.36(.52)$ & $1.66(.31)$ & $-5.78^{* *}$ & -0.7 & 106 \\
\hline Long-term mating & $.94(.38)$ & $1.79(.41)$ & $-12.84^{* *}$ & -2.15 & 106 & $.97(.41)$ & $1.81(.39)$ & $-13.18^{* *}$ & -2.1 & 106 \\
\hline
\end{tabular}

$* p<.05$.

** $p<.01$

sensation seeking, risk taking and reactive aggression in secondary psychopathy could be adaptive in intrasexual competition (Weiss, Egan, \& Figueredo, 2004). Nevertheless, unlike primary psychopathic individuals who are cunning, secondary psychopathic individuals perhaps are more likely to be caught and punished (Wilkowski \& Robinson, 2008). Therefore, the "good genes" of psychopathy potentially pertain more to primary psychopathy. In the current study, we explore this argument.

What also remains un-investigated is whether primary or secondary psychopathic individuals find their equivalents attractive. Assortative mating is the process by which individuals select romantic partners who are similar to them on a range of physical, psychological, educational and socio-economic factors (Thiessen \& Gregg, 1980). Assortative mating is adaptive because it increases familial genetic relatedness, which helps bond and promote communication between family members (Thiessen \& Gregg, 1980). Shared traits and lifestyles increase relationship satisfaction (Gonzaga, Carter, \& Galen Buckwalter, 2010) and marital quality (Luo \& Klohnen, 2005), and therefore improve relationship longevity. Long-term relationship commitment is conducive to high-quality parenting, however, individuals who are high in secondary psychopathic traits also choose similar partners to them. Antisocial behaviour (Krueger, Moffitt, Caspi, Bleske, \& Silva, 1998), and substance use and criminal propensity (Boutwell, Beaver, \& Barnes, 2012) are associated with assortative mating. Currently, whether mate choice for similarity also pertains to primary psychopathic traits remains, we believe, un-investigated. Considering that assortative mating encourages high-quality child-care queries how it can benefit those with psychopathy who invest in mating effort. However, partners who share proclivities to cheat and deceive each other should experience relationship dissatisfaction and consequently move on to a new partner (and have more children) (Olderbak \& Figueredo, 2010). Alternatively, psychopathic individuals might choose a similar partner because they enjoy the drama of the relationship (Jonason, Valentine, Li, \& Harbeson, 2011). It is arguable then, that primary or secondary psychopathic individuals do not differentiate between short and long-term relationships because mating effort is always more important than parenting.

In the current study, we investigated mate choice for primary and secondary psychopathic individuals for short and long-term mating.
As well as looking at the overall preference, we were interested in assortative mating for these traits. This is the first study that examines the attractiveness of the two psychopathy sub-types, elucidating the success of these traits in the mating domain.

\section{Method}

\subsection{Participants}

Two hundred and fifty-eight participants, of which 107 were male $\left(M_{\text {age }}: 37.48, S D=12.40\right)$ and 151 female $\left(M_{\text {age }}: 40.72, S D=12.03\right)$ were recruited via a crowd-sourcing company from countries whose first language is English (United States, Canada, Australia and the United Kingdom).

\subsection{Measures}

\subsubsection{Self-Report Psychopathy Scale (SRP-III)}

The SRP-III (Paulhus, Neumann, \& Hare, 2009) is a 64-item, selfreport questionnaire used to measure psychopathy in a non-clinical population. A 5-point Likert scale ( $1=$ disagree strongly, $5=$ agree strongly) measures how much participants agree with statements such as "I have tricked someone into giving me money". Thirty-two items each are summed to provide scores for primary psychopathy and secondary psychopathy. Both had good internal reliability (Cronbach's alpha $=.87$ and .87 respectively).

\subsubsection{Personality profile vignettes}

Personality profiles were based on the SRP-III and described individuals as high or low in primary psychopathy, and high or low in secondary psychopathy (see Appendix A). Twelve vignettes were created, three each for high and low primary psychopathy, and high and low secondary psychopathy. Primary psychopathic profiles described calculating and un-empathetic individuals. Secondary psychopathic profiles described impulsive and criminal individuals. Non-psychopathic profiles were empathetic and stable. Vignettes were made sex specific (e.g., changing admiration of Donald Trump for the male high primary psychopathy vignette to Kim Kardashian for the female equivalent).

Table 2

Partial correlations between men and women's ratings of high and low primary and secondary personality profiles.

\begin{tabular}{|c|c|c|c|c|c|c|}
\hline & \multicolumn{3}{|c|}{ Primary psychopathy } & \multicolumn{3}{|c|}{ Secondary psychopathy } \\
\hline & High & Low & $z$ & High & Low & $z$ \\
\hline $\begin{array}{l}\text { Short-term mating } \\
\text { Long-term mating }\end{array}$ & $\begin{array}{c}.09 / .09 \\
.03 / .30^{* *}\end{array}$ & $\begin{array}{l}.06 / .05 \\
.10 /-.10\end{array}$ & $\begin{array}{l}-1.09 / .34 \\
-0.51 / 3.55^{\text {** }}\end{array}$ & $\begin{array}{l}.19 / .26^{* *} \\
.18 / .06\end{array}$ & $\begin{array}{l}-.01 /-.01 \\
-.09 /-.11\end{array}$ & $\begin{array}{l}1.46 / 2.38^{*} \\
1.97 / /^{*} 1.50\end{array}$ \\
\hline
\end{tabular}

Note: $z$ is Steiger's $z$ to compare correlations between high and low PP and SP mate preference. Men are reported above the diagonal, women are reported below the diagonal.

* $p<.05$.

** $p<.01$ 
Table 3

Stepwise regression of higher primary psychopathy mate preference in short and long-term mating.

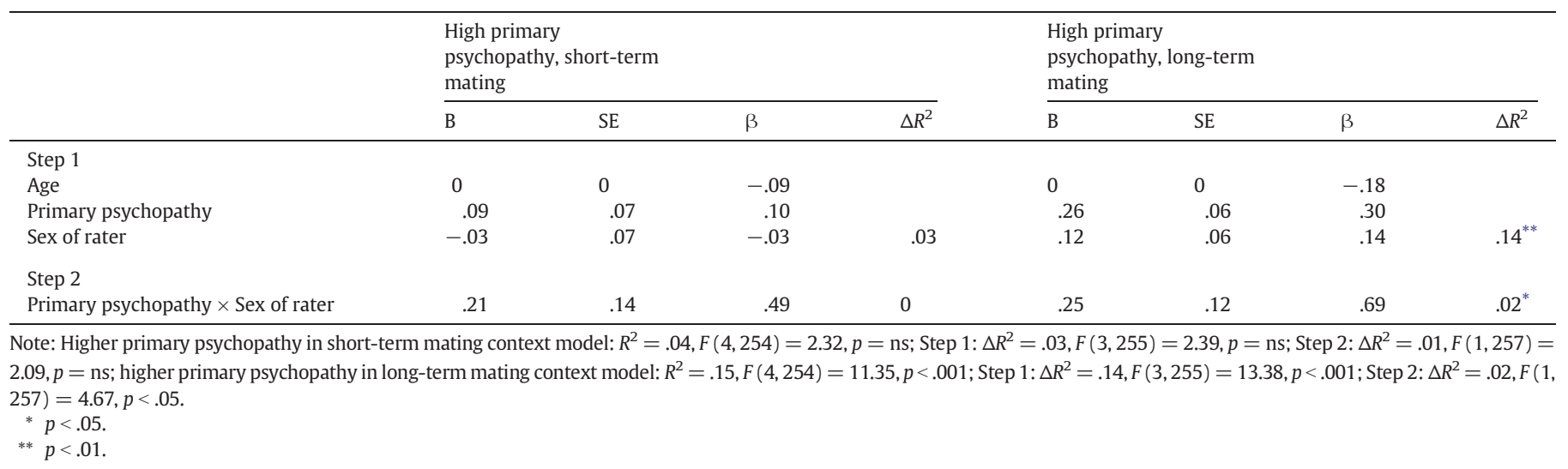

Participants used a 5 -point Likert scale $(1=$ not at all attractive to $5=$ extremely attractive) to rate the profiles on the following criteria: onenight stand; physical attractiveness; potential husband/wife and potential parent. One-night stand and physical attractiveness ratings were summed and averaged to produce a score for short-term mating preference; ratings for potential husband/wife and potential parent were summed and averaged to produce a score for long-term mating preference. There were eight mating preference scores (per sex) in total: high/ low, primary/secondary psychopathy in short/long-term mating. Vignettes had moderate to good internal consistency (Cronbach's alpha $=.55$ to .86$)$.

\subsection{Procedure}

Participants took part in an online survey titled "Personality Style and Mating Preferences". They were allocated to twelve opposite-sex "personality profile" vignettes, that were alternately presented on individual web-pages: high and low primary psychopathic, then high and low secondary psychopathic to rate for short and long-term mating. Next, participants completed the SRP-III and were thanked for their participation. Participants were paid $10 \llbracket$ for their time.

\section{Results}

Two independent samples $t$-tests showed that men rated themselves higher in both primary $\left(M_{\text {male }}=2.76, S D=.42 ; M_{\text {female }}=\right.$ $2.30, S D=47 ; t(256)=8.07, p<.001, d=1.03)$ and secondary psychopathy $\left(M_{\text {male }}=2.44, S D=.55 ; M_{\text {female }}=2.02, S D=.44\right.$, $t(256)=6.80, p<.001, d=0.84)$ than women. A series of dependent samples $t$-tests showed that men and women rated higher individuals lower in primary and secondary psychopathic traits for both short and long-term mating (Table 1 ).

To determine if men and women scoring higher in primary and secondary psychopathic traits prefer partners of a similar personality, we conducted a series of partial correlations (Table 2), controlling for secondary psychopathy in the primary psychopathy analyses, and primary psychopathy in the secondary psychopathy analyses. This was to ensure that relationships were determined by the particular psychopathy variant, rather than their shared variance. Owing to the age range of our participants, we controlled for age. We adjusted the alpha level to .001 to correct for multiple testing. Women scoring higher in primary psychopathy rated primary psychopathic profiles higher for long-term mating. Women scoring higher in secondary psychopathy rated secondary psychopathic profiles higher, but for both short and long-term mating. Men scoring higher in primary or secondary psychopathy did not rate higher or lower their equivalents in either mating context.

To further explore the effect of the sex of the rater on mate preference, we performed eight, two-step hierarchical regressions (Tables 3 , 4, 5 and 6), with each psychopathy variant in each mating context as the dependent variable (for example, high primary psychopathy for short-term mating, high primary psychopathy for long-term mating etc.). The first step in the model regressed age, the psychopathy variant, and the sex of the rater on to mating preference. The second step added an interaction variable of psychopathy variant and sex of the rater. Age, primary psychopathy and sex of the rater were uniquely predictive of higher ratings for primary psychopathic partners in long-term mating, $\beta=-.18, t=-2.94, p<.05 ; \beta=.30, t=4.33, p<.001 ; \beta=.14$, $t=2.16, p<.05$, respectively. With the addition of the interaction variable, standardized betas for primary psychopathy and sex of the rater reduced, although age remained significant, $\beta=-.18, t=-2.97$,

Table 4

Stepwise regression of lower primary psychopathy mate preference in short and long-term mating.

\begin{tabular}{|c|c|c|c|c|c|c|c|c|}
\hline & \multicolumn{4}{|c|}{$\begin{array}{l}\text { Low primary } \\
\text { psychopathy, } \\
\text { short-term mating }\end{array}$} & \multicolumn{4}{|c|}{$\begin{array}{l}\text { Low primary psychopathy, } \\
\text { long-term mating }\end{array}$} \\
\hline & B & SE & $\beta$ & $\overline{\Delta R^{2}}$ & B & SE & $\beta$ & $\Delta R^{2}$ \\
\hline \multicolumn{9}{|l|}{ Step 1} \\
\hline Age & 0 & 0 & 0.03 & & 0 & 0 & 0.13 & \\
\hline Primary psychopathy & 0.05 & 0.05 & 0.07 & & -0.1 & 0.06 & -0.12 & \\
\hline Sex of rater & 0 & 0.05 & 0 & 0 & -0.02 & 0.06 & -0.03 & $.04^{* * *}$ \\
\hline \multicolumn{9}{|l|}{ Step 2} \\
\hline Primary psychopathy $\times$ Sex of rater & 0.03 & 0.11 & 0.09 & 0 & -0.07 & 0.11 & -0.22 & 0 \\
\hline
\end{tabular}

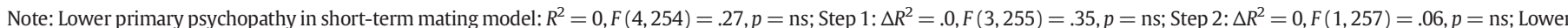
primary psychopathy in the long-term mating model; $R^{2}=.04, F(4,254)=2.69, p=\mathrm{ns}$; Step $1: \Delta R^{2}=.04, F(3,255)=3.46, p<.05 ;$ Step $2: \Delta R^{2}=0, F(1,257)=.41, p=$ ns. $* p<.05$.

** $p<.01$. 
Stepwise regression of higher secondary psychopathy mate preference in short and long-term mating.

\begin{tabular}{|c|c|c|c|c|c|c|c|c|}
\hline & \multicolumn{4}{|c|}{$\begin{array}{l}\text { Higher secondary } \\
\text { psychopathy, short-term } \\
\text { mating }\end{array}$} & \multicolumn{4}{|c|}{$\begin{array}{l}\text { Higher secondary } \\
\text { psychopathy, long-term } \\
\text { mating }\end{array}$} \\
\hline & $\mathrm{B}$ & SE & $\beta$ & $\Delta R^{2}$ & B & SE & $\beta$ & $\Delta R^{2}$ \\
\hline \multicolumn{9}{|l|}{ Step 1} \\
\hline Age & 0 & 0 & -.14 & & 0 & 0 & -.18 & \\
\hline Secondary psychopathy & .19 & .07 & .19 & & .18 & .06 & .20 & \\
\hline Sex & 0 & .07 & 0 & $.07^{* *}$ & .04 & .06 & .04 & $.09^{* *}$ \\
\hline \multicolumn{9}{|l|}{ Step 2} \\
\hline Secondary psychopathy $\times$ Sex of rater & .43 & .13 & .87 & $.04^{* *}$ & .26 & .11 & 63 & $.02^{*}$ \\
\hline \multicolumn{9}{|c|}{$\begin{array}{l}\text { Note: Higher secondary psychopathy in short-term mating model: } R^{2}=.11, F(4,254)=7.60, p<.001 ; \text { Step } 1: \Delta R^{2}=.07, F(3,255)=6.38, p<.001 ; \text { Step } 2: \Delta R^{2}=.04, F(1,257)=10.53 \\
p=.001 \text {; Higher secondary psychopathy in long-term mating model: } R^{2}=.11, F(4,254)=7.51, p<.001 ; \text { Step } 1: \Delta R^{2}=.09, F(3,255)=8.05, p<.001 ; \text { Step } 2: \Delta R^{2}=.02, F(1,257)= \\
5.48, p<.05 \text {. } \\
\quad * p<.05 .\end{array}$} \\
\hline
\end{tabular}

$p<.05$. The interaction variable was a significant predictor, $\beta=.69, t=$ $2.16, p<.05$. No other models for primary psychopathy mating preference produced significant predictors.

Age and secondary psychopathy significantly predicted higher ratings for secondary psychopathic partners for short-term mating, $\beta=-.14, t=-2.18, p<.05 ; \beta=.19, t=2.70, p<.05$, respectively. With the addition of the interaction variable, the standardized betas for age and secondary psychopathy remained significant, $\beta=-.14$, $t=2.15, p<.05, \beta=-.43, t=2.14, p<.05$, and became significant for sex, $\beta=-87, t=-3.16, p<.05$. The interaction variable was a significant predictor, $\beta=.87, t=3.25, p=.001$. Age and secondary psychopathy significantly predicted higher ratings for secondary psychopathic partners in long-term mating, $\beta=-.18, t=-2.80$, $p<.05 ; \beta=.20, t=3.0, p<.05$, respectively. With the addition of the interaction variable, age remained a significant predictor, $\beta=-.17$, $t=-2.80, p<.05$, sex became a significant predictor, $\beta=-.59$, $t=-2.12, p<.05$, as did the interaction variable, $\beta=.63, t=2.34$, $p<.05$. Neither two models produced significant predictors for mates preference for lower secondary psychopathy for short-term mating, however for long-term mating, age was a significant positive predictor, $\beta=.21, t=3.17, p<.05$ and remained the same with the addition of the interaction variable.

The forms of significant interactions were examined by the post-hoc probing methods suggested by Process (Hayes, 2012) and tested the association between preference for primary psychopathic partners for long-term mating and sex at high, mean and low levels of primary psychopathy. The significance of these simple slopes was calculated. We looked at un-standardized beta and standard error at 95\% confidence intervals that did not include zero. The form of the interaction was plotted by computing the full regression equation at high (1 SD above the mean) and low (1 SD below the mean) levels of the two predictors (i.e., primary psychopathy and the interaction variable). The interaction between primary psychopathy and sex of the rater was significant in predicting preference for primary psychopathic partners for long-term mating $\left(\Delta R^{2}=.02, F(1,253)=4.67, p=.03\right)$. We also tested for the interaction between secondary psychopathy and sex of the rater, and found that it was significant in predicting preference for secondary psychopathic partners for both short $\left(\Delta R^{2}=.04, F(1,253)=10.53, p=\right.$ $.001)$ and long-term mating $\left(\Delta R^{2}=.02, F(1,253)=5.48, p=.02\right)$. Figs. 1, 2 and 3 illustrate these interactions.

\section{Discussion}

To our knowledge, this is the first study that has investigated mating preferences and primary and secondary psychopathy. Contrary to expectations, people preferred low primary and secondary psychopathic individuals in both short and long-term relationships. With regard to assortative mating, primary psychopathic women preferred similar partners for long-term relationships, and secondary psychopathic women preferred similar partners for both short and long-term relationships.

It is interesting that men and women did not consider short-term relationships with either a primary or secondary psychopathic partner attractive, despite previous evidence to the contrary (Jonason, Luevano, \& Adams, 2012; Jonason et al., 2015) which therefore challenges the "good genes" hypothesis. For secondary psychopathy, the negative outcomes are perhaps more salient (e.g., Ray et al., 2009; Schmitt \& Schmitt

Table 6

Stepwise regression of lower secondary psychopathy mate preference in short and long-term mating.*

\begin{tabular}{|c|c|c|c|c|c|c|c|c|}
\hline & \multicolumn{4}{|c|}{$\begin{array}{l}\text { Lower secondary } \\
\text { psychopathy, } \\
\text { short-term mating }\end{array}$} & \multicolumn{4}{|c|}{$\begin{array}{l}\text { Lower secondary } \\
\text { psychopathy, long-term } \\
\text { mating }\end{array}$} \\
\hline & B & SE & $\beta$ & $\Delta R^{2}$ & B & SE & $\beta$ & $\Delta R^{2}$ \\
\hline \multicolumn{9}{|l|}{ Step 1} \\
\hline Age & 0 & 0 & .06 & & 0 & 0 & .21 & \\
\hline Secondary psychopathy & .04 & .05 & .06 & & -.09 & .05 & -.12 & \\
\hline Sex & .02 & .05 & .02 & 0 & .04 & .05 & .05 & $.08^{* *}$ \\
\hline \multicolumn{9}{|l|}{ Step 2} \\
\hline Secondary psychopathy $\times$ Sex of rater & .07 & .09 & .23 & 0 & .05 & .10 & .13 & 0 \\
\hline
\end{tabular}




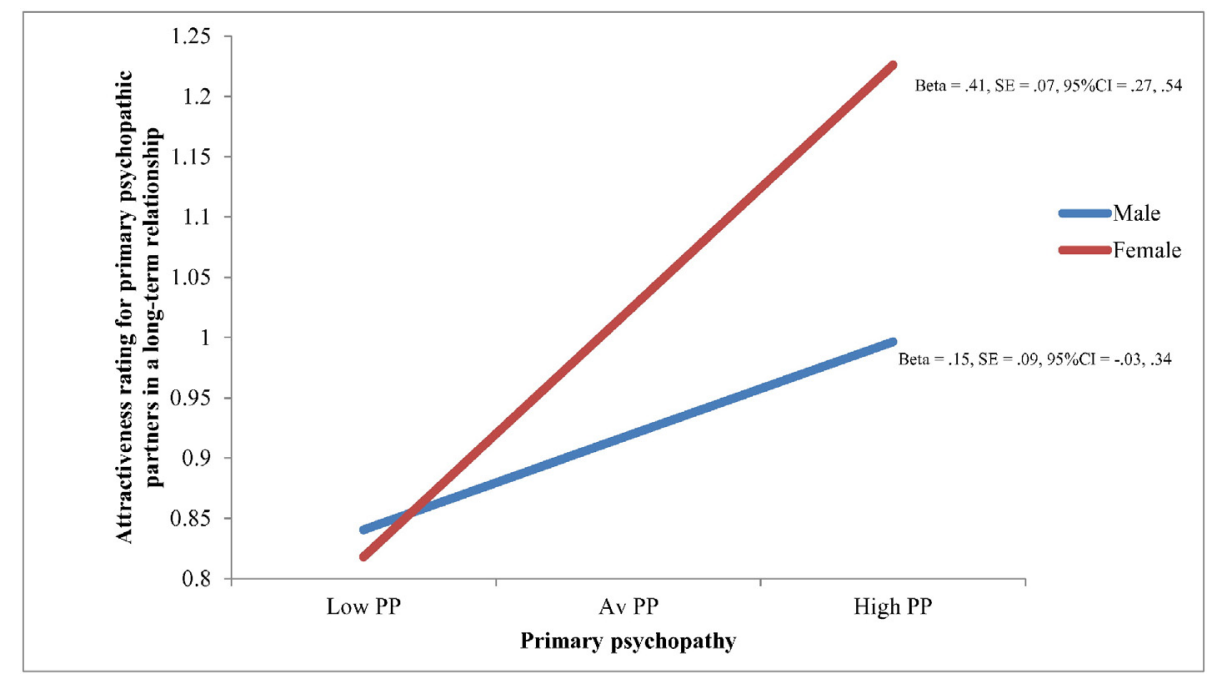

Fig. 1. Attractiveness ratings for primary psychopathic partners in a long-term relationship split by low, average and high primary psychopathy scores and sex.

\& Newman, 1999; Whiteside \& Lynam, 2001), although primary psychopathic individuals were expected to be attractive because of their success in business (Babiak et al., 2010) and other high-ranking professions (Skeem et al., 2011). However, the average age of our female participants was significantly higher than those in a previous study that found preference for psychopathic men in short-term relationships (Jonason et al., 2015). Indeed, during ovulation young women can erroneously judge "cads" for "good dads" (Durante et al., 2012). Nevertheless, this does not explain the pattern of mate choice in men, who are not subject to fertility time constraints (Easton, Confer, Goetz, \& Buss, 2010). Considering the adversarial nature of primary and secondary psychopathic individuals, it would seem adaptive to be able to identify and avoid involvement with them on any level. Thus, the mating success of those individuals may rest solely on their ability to manipulate and take advantage, rather than the penchant of other people for "bad" boys or girls.

Our findings were also suggestive of assortative mating in primary and secondary psychopathy, but only in younger women. Either these women need to ensure that they are able to move from partner to partner by engaging in problematic relationships that fail (Olderbak \& Figueredo, 2010), or they are subject to the same types of parental investment issues that non-psychopathic women are in terms of their primary role in parenting (Trivers, 1972). Perhaps primary and secondary psychopathic men do in fact offer "good genes" and resource acquisition ability (Mullins-Sweatt et al., 2010), but it is only their female equivalents that can benefit from them, by being able to predict and manage the toxic nature of their personalities that non-psychopathic women usually avoid. Primary psychopathic women might be protected by their inability to become emotionally involved (Lishner, Swim, Hong, \& Vitacco, 2011), and remain calculating and manipulative in achieving long-term goals. Cognitive egocentrism and deficits in Theory of Mind may also keep them in denial about the suitability of their mate choice (Ali, Amorim, \& Chammorro-Premuzic, 2009; Bresin, Boyd, Ode, \& Robinson, 2013). Clearly more research is needed to investigate what the proximate mechanisms for women's assortative preferences for primary and secondary psychopathy are.

Men scoring higher in primary or secondary psychopathic traits did not show any preference for mate similarity in either mating context, suggesting a non-discriminant mating style. For men whose focus is on short-term mating, such an approach is probably strategic, as they don't have to dedicate time to pursuing one type of woman over another. Evidently, primary or secondary psychopathic women confer no fitness advantage to them over non-psychopathic women. Alternatively, the lack of differentiation also suggests that primary and secondary psychopathic men are unable to identify the adversarial characteristics of a similar mate. In primary psychopathic men, this might again be due to deficits in Theory of Mind or cognitive egocentrism (Ali et al., 2009; Bresin, Boyd, Ode, \& Robinson, 2013). In secondary psychopathic men,

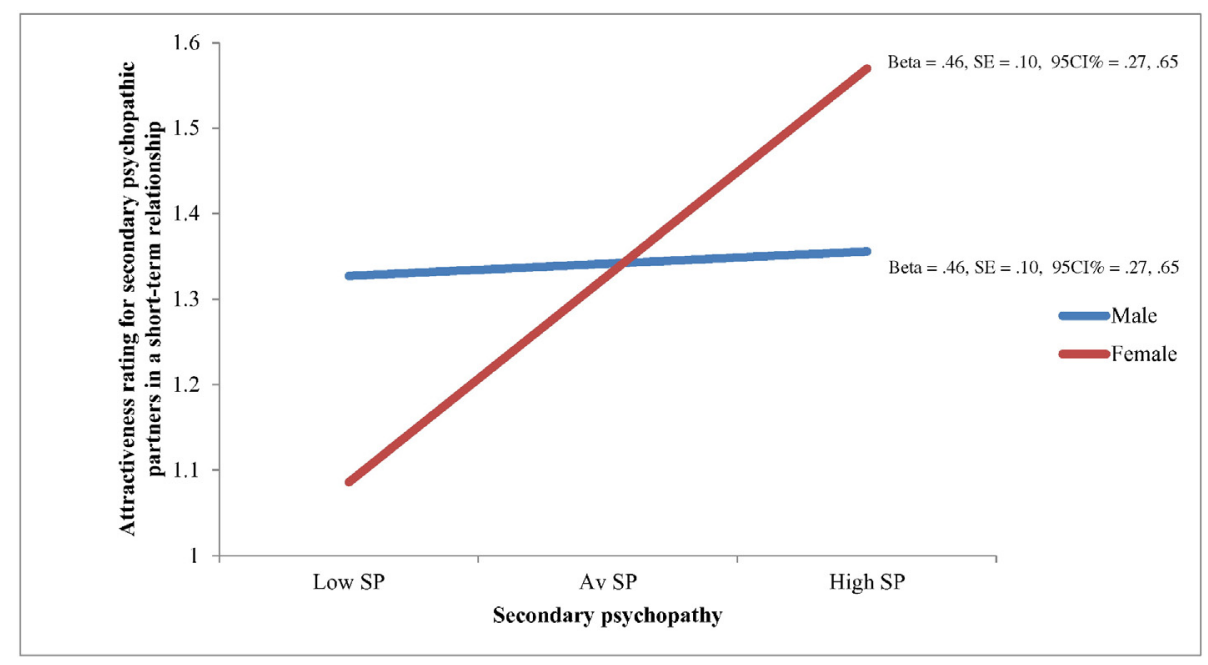

Fig. 2. Attractiveness ratings for secondary psychopathic partners in a short-term relationship split by low, average and high secondary psychopathy scores and sex. 


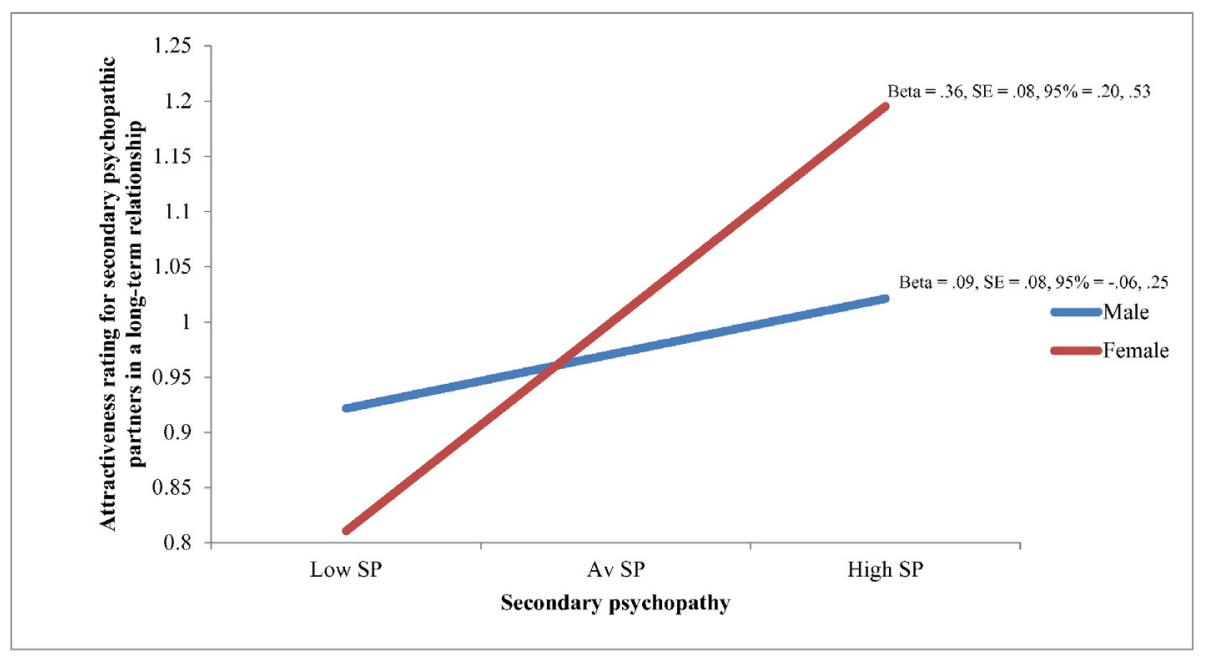

Fig. 3. Attractiveness ratings for secondary psychopathic partners in a long-term relationship split by low, average and high secondary psychopathy scores and sex.

anxiety, negative urgency and the inability to learn from their mistakes might pay a part in poor judgement (Levenson et al., 1995; Whiteside \& Lynam, 2001; Wilkowski \& Robinson, 2008). In all cases, further research is needed to elucidate how primary and secondary psychopathic men and women choose their mates.

There are limitations to the current study. We did not control for ovulation, which can distort women's evaluations of potential mates (Durante et al., 2012). A future study could explore if psychopathy variant interacts with ovulation in influencing mate preference. Further, self-report measures are subject to issues including self-biasing, however for this exploratory study they are sufficient and present the opportunity for using different measures in future research.

By investigating primary and secondary psychopathy specifically, this study has made a unique contribution to a small, but emerging research area that looks at the appeal of individuals who harbour psychopathic traits. In conclusion, men and women are adaptively able to identify and therefore avoid the pitfalls of romantic involvement with either a primary or secondary psychopathic partner. Those pitfalls seem less problematic for those that are psychopathic, and positively alluring for primary and secondary psychopathic women.

\section{Appendix A. Supplementary data}

Supplementary data to this article can be found online at http://dx. doi.org/10.1016/j.paid.2015.12.024.

\section{References}

Ali, F., Amorim, I. S., \& Chamorro-Premuzic, T. (2009). Empathy deficits and trait emotional intelligence in psychopathy and Machiavellianism. Personality and Individual Differences, 47(7), 758-762.

Anestis, M. D., Anestis, J. C., \& Joiner, T. E. (2009). Affective considerations in antisocial behavior: An examination of negative urgency in primary and secondary psychopathy. Personality and Individual Differences, 47(6), 668-670.

Babiak, P., Neumann, C. S., \& Hare, R. D. (2010). Corporate psychopathy: Talking the walk. Sciences-New York, 193(April), 174-193.

Boutwell, B. B., Beaver, K. M., \& Barnes, J. C. (2012). More alike than different: Assortative mating and antisocial propensity in adulthood. Criminal Justice and Behavior, 39(9), 1240-1254.

Bresin, K., Boyd, R. L., Ode, S., \& Robinson, M. D. (2013). Egocentric perceptions of the environment in primary, but not secondary, psychopathy. Cognitive Therapy and Research, 37(2), 412-418.

Donahue, J. J., McClure, K. S., \& Moon, S. M. (2014). The relationship between emotion regulation difficulties and psychopathic personality characteristics. Personality Disorders: Theory, Research, and Treatment, 5(2), 186-194.

Durante, K. M., Griskevicius, V., Simpson, J. A., Cantú, S. M., \& Li, N. P. (2012). Ovulation leads women to perceive sexy cads as good dads. Journal of Personality and Social Psychology, 103(2), 292-305.
Easton, J. A., Confer, J. C., Goetz, C. D., \& Buss, D. M. (2010). Reproduction expediting: Sexual motivations, fantasies, and the ticking biological clock. Personality and Individual Differences, 49(5), 516-520.

Fulton, J. J., Marcus, D. K., \& Payne, K. T. (2010). Psychopathic personality traits and risky sexual behavior in college students. Personality and Individual Differences, 49(1), 29-33.

Gonzaga, G. C., Carter, S., \& Galen Buckwalter, J. (2010). Assortative mating, convergence, and satisfaction in married couples. Personal Relationships, 17(4), 634-644.

Griskevicius, V., Tybur, J. M., Sundie, J. M., Cialdini, R. B., Miller, G. F., \& Kenrick, D. T. (2007). Blatant benevolence and conspicuous consumption: When romantic motives elicit strategic costly signals. Journal of Personality and Social Psychology, 93(1), 85-102.

Hare, R. D. (2003). Manual for the psychopathy checklist-revised. Toronto, Ontario, Canada: Multi-Health Systems.

Hayes, A. F. (2012). PROCESS: A versatile computational tool for observed variable mediation, moderation, and conditional process modeling [white paper].

Jonason, P. K., Li, N. P., \& Buss, D. M. (2010). The costs and benefits of the Dark Triad: Implications for mate poaching and mate retention tactics. Personality and Individual Differences, 48(4), 373-378.

Jonason, P. K., Li, N. P., Webster, G. D., \& Schmitt, D. P. (2009). The Dark Triad: Facilitating a short-term mating strategy in men. European Journal of Personality, 23, 5-18.

Jonason, P. K., Luevano, V. X., \& Adams, H. M. (2012). How the Dark Triad traits predict relationship choices. Personality and Individual Differences, 53(3), 180-184.

Jonason, P. K., Lyons, M., \& Blanchard, A. (2015). Birds of a "bad" feather flock together: The Dark Triad and mate choice. Personality and Individual Differences, 78, 34-38.

Jonason, P. K., Valentine, K. A., Li, N. P., \& Harbeson, C. L. (2011). Mate-selection and the Dark Triad: Facilitating a short-term mating strategy and creating a volatile environment. Personality and Individual Differences, 51(6), 759-763.

Krueger, R. F., Moffitt, T. E., Caspi, A., Bleske, A., \& Silva, P. A. (1998). Assortative mating for antisocial behavior: Developmental and methodological implications. Behavior Genetics, 28(3), 173-186.

Kruger, D. J., Fisher, M., \& Jobling, I. (2003). Proper and dark heroes as dads and cads: Alternative mating strategies in British Romantic literature. Human Nature, 14(3), 305-317.

Lee, K., Ashton, M. C., Wiltshire, J., Bourdage, J. S., Visser, B. A., \& Gallucci, A. (2013). Sex, power, and money: Prediction from the Dark Triad and Honesty-Humility. European Journal of Personality, 27(2), 169-184.

Levenson, M. R., Kiehl, K. A., \& Fitzpatrick, C. M. (1995). Assessing psychopathic attributes in a noninstitutionalized population. Journal of Personality and Social Psychology, 68(1), 151-158.

Lishner, D. A., Swim, E. R., Hong, P. Y., \& Vitacco, M. J. (2011). Psychopathy and ability emotional intelligence: Widespread or limited association among facets? Personality and Individual Differences, 50(7), 1029-1033.

Luo, S., \& Klohnen, E. C. (2005). Assortative mating and marital quality in newlyweds: a couple-centered approach. Journal of Personality and Social Psychology, 88(2), 304-326.

Mealey, L. (1995). Primary sociopathy (psychopathy) is a type, secondary is not. Behavioral and Brain Sciences, 18, 579-599.

Mouilso, E. R., \& Calhoun, K. S. (2012). A mediation model of the role of sociosexuality in the associations between narcissism, psychopathy, and sexual aggression. Psychology of Violence, 2(1), 16-27.

Mullins-Sweatt, S. N., Glover, N. G., Derefinko, K. J., Miller, J. D., \& Widiger, T. A. (2010). The search for the successful psychopath. Journal of Research in Personality, 44(4), 554-558.

Olderbak, S. G., \& Figueredo, A. J. (2010). Life history strategy as a longitudinal predictor of relationship satisfaction and dissolution. Personality and Individual Differences, 49(3), 234-239.

Paulhus, D. L., Neumann, C. S., \& Hare, R. D. (2009). Manual for the Self-Report Psychopathy Scale. Toronto, Ontario: Multi-Health Systems. 
Ray, J., Poythress, N., Weir, J., \& Rickelm, A. (2009). Relationships between psychopathy and impulsivity in the domain of self-reported personality features. Personality and Individual Differences, 46(2), 83-87.

Schmitt, W. A., \& Newman, J. P. (1999). Are all psychopathic individuals low anxious? Journal of Abnormal Psychology, 108(2), 353-358.

Skeem, J. L., Polaschek, D. L. L., Patrick, C. J., \& Lilienfeld, S. O. (2011). Psychopathic personality: Bridging the gap between scientific evidence and public policy. Psychological Science in the Public Interest, 12, 95-162.

Smith, C., Hadden, B. W., Webster, G. D., Jonason, P. K., Gesselman, A. N., \& Crysel, L. C. (2014). Mutually attracted or repulsed? Actor-partner interdependence models of Dark Triad traits and relationship outcomes. Personality and Individual Differences, 67, 35-41.

Thiessen, D., \& Gregg, B. (1980). Human assortative mating and genetic equilibrium: An evolutionary perspective. Ethology and Sociobiology, 1(2), 111-140.

Trivers, R. L. (1972). Parental investment and sexual selection. In B. Campbell (Ed.), Sexual selection and the descent of man, 1871-1971 (pp. 136-179). Chicago: Aldine.

Verona, E., Patrick, C. J., \& Joiner, T. E. (2001). Psychopathy, antisocial personality, and suicide risk. Journal of Abnormal Psychology, 110(3), 462-470.
Vidal, S., Skeem, J., \& Camp, J. (2010). Emotional intelligence: Painting different paths for low-anxious and high-anxious psychopathic variants. Law and Human Behavior 34(2), 150-163.

Visser, B. A., Pozzebon, J. A., Bogaert, A. F., \& Ashton, M. C. (2010). Psychopathy, sexual behavior, and esteem: It's different for girls. Personality and Individual Differences, 48(7), 833-838.

Weiss, A., Egan, V., \& Figueredo, A. J. (2004). Sensational interests as a form of intrasexual competition. Personality and Individual Differences, 36(3), 563-573.

Whiteside, S. P., \& Lynam, D. R. (2001). The five factor model and impulsivity: Using a structural model of personality to understand impulsivity. Personality and Individual Differences, 30, 669-689.

Wilkowski, B. M., \& Robinson, M. D. (2008). Putting the brakes on antisocial behavior: Secondary psychopathy and post-error adjustments in reaction time. Personality and Individual Differences, 44(8), 1807-1818. 